\title{
Two new species of Fridericia (Annelida: Enchytraeidae) from Hungarian caves
}

\author{
Klára DÓZSA-FARKAS ${ }^{1}$, Hajnalka NAGY² \& Tamás FELFÖLDI ${ }^{3, *}$ \\ ${ }^{1}$ Department of Systematic Zoology and Ecology, ELTE Eötvös Loránd University, \\ H-1117 Budapest, Pázmány Péter sétány 1/C, Hungary. \\ ${ }^{2,3}$ Department of Microbiology, ELTE Eötvös Loránd University, H-1117 Budapest, \\ Pázmány Péter sétány $1 / \mathrm{C}$, Hungary. \\ *Corresponding author: tamas.felfoldi@gmail.com \\ 1Email: nhajni6@gmail.com \\ 2Email:kdozsafarkas@gmail.com \\ ${ }^{1}$ urn:1sid:zoobank.org:author:4A08693E-3C7D-432E-8BCA-CBBDF7E36D02 \\ ${ }^{2}$ urn:1sid:zoobank.org:author:13D87FB8-C834-4CD7-AC35-219D77009297 \\ ${ }^{3}$ urn:1sid:zoobank.org:author:F0CD45C8-0140-4E52-A996-080FE186EB72
}

\begin{abstract}
Cave research in Hungary has developed a lot in the last decade. As a part of this progress, enchytraeid specimens were collected from Hungarian caves and were subsequently characterized by comparative morphological and molecular taxonomic analyses. Molecular phylogenetic studies based on ITS, $\mathrm{CO} 1$ and $\mathrm{H} 3$ sequences and morphological results confirmed that these specimens represented two species new to science. The descriptions of Fridericia baradlana sp. nov. and Fridericia spelaeophila sp. nov. are presented in this paper.
\end{abstract}

Keywords. Clitellata, troglophile, morphological and molecular taxonomy, Northern Mountain Range of Hungary.

Dózsa-Farkas K., Nagy H. \& Felfödi T. 2019. Two new species of Fridericia (Annelida: Enchytraeidae) from Hungarian caves. European Journal of Taxonomy 553: 1-18. https://doi.org/10.5852/ejt.2019.553

\section{Introduction}

Aquatic oligochaetes living in the subterranean environment have been studied extensively and significant results have been published related to several aspects of their biology and ecology (see the review of Creuzé des Châtelliers et al. 2009). Contrary to this, only few data are available on cave enchytraeids, and in most of these publications Hungarian cave habitats were characterized. Outside Hungary, only Botea $(1973,1984)$ studied such environments, and he described seven new species from Romanian caves, but these novel species later proved to be nomen dubia (Schmelz 2003; Schmelz \& Collado 2010). Unfortunately, his material was lost, therefore uncertainties exist regarding the published data. 
In Hungary, Professor Endre Dudich played a prominent role in the study of cave animals; in his monograph published in 1932, he recorded 262 species from the Baradla cave (part of the BaradlaDomica cave system, Aggtelek Karst, Hungary) (Dudich 1932). In further research carried out under his supervision (Dózsa-Farkas 1970, Dózsa-Farkas 1974), this was succeeded by the detection of 13 enchytraeid species and additionally by the description of four species new to science (Cernosvitoviella aggtelekiensis Dózsa-Farkas, 1970, Enchytronia christenseni Dózsa-Farkas, 1970, Fridericia reducata Dózsa-Farkas, 1974, and F. semisetosa Dózsa-Farkas, 1970). Subsequent studies have confirmed that these species (including the newly described ones) cannot be considered troglobionts, since they were later found in various aboveground habitats (Dózsa-Farkas 2019).

Cave research in Hungary has developed considerably in the last decade (e.g. Erôss et al. 2012; Anda et al. 2017). From the Baradla-Domica cave system, 583 invertebrate taxa have already been reported (Salamon et al. 2015). Recently, zoologist caver colleagues also collected enchytraeid specimens, namely from the caves Baradla, Szepesi and Láner Olivér and from the Kis-kőháti shaft (these are located in the Northern Mountain Range of Hungary, the latter three in the Bükk Mts). Based on the results of traditional morphological and molecular taxonomic analyses, these specimens are considered to represent two species new to science. In this article, the descriptions of these two new enchytraeid species are given.

\title{
Materials and methods
}

\author{
Abbreviations \\ $\mathrm{CO} 1=$ Cytochrome $\mathrm{c}$ Oxidase subunit I \\ ELTE $=$ Eötvös Loránd Tudományegyetem (Eötvös Loránd University) \\ $\mathrm{H} 3=$ Histone 3 \\ ITS $=$ Internal Transcribed Spacer \\ $\mathrm{PCR}=$ Polymerase Chain Reaction
}

\section{Methods of morphological examination}

In 2013 and 2014, specimens were picked up individually and fixed immediately in 96\% ethanol. In 2015 and 2018, live worm specimens were brought into the laboratory together with some pieces of decaying wood. From the decaying wood and from the clay on it, several worms were extracted by the wet funnel method (O'Connor 1962). The extracted enchytraeids were observed and measured in vivo, then fixed and preserved in $70 \%$ ethanol. The majority of these specimens and the majority of those fixed on site (collected in 2013 and 2014) were stained with borax-carmine, and then passed through an ethanol dehydration series (from $70 \%$ to absolute), mounted temporarily in clove oil, then permanently in Euparal between two coverslips. Hence the worms were observable from both sides (Schmelz 2003). Some specimens were prepared without staining. All the important morphological characters were recorded, drawn and photographed (Axio Imager.A2 microscope with differential interference contrast illumination, AxioCam MRc 5 [Zeiss] digital camera, Axiovision software) in vivo and fixed alike. Due to their large body size, fixed specimens of F. spelaeophila sp. nov. were often cut into two parts and the forepart was opened dorsally and stained. Slides containing the forepart of the whole-mounted worms were marked with ' $a$ ' and slides with the posterior parts with ' $b$ '. In all micrographs presented in this study, the orientation of specimens is the same; the head is either on the left side or at the top of the picture.

Selected material was catalogued with letters for the holotypes ('F') and paratypes ('P'), with collection numbers and with slide numbers, and was deposited in the collection of the Department of Systematic Zoology and Ecology, ELTE. 


\section{Methods of molecular analysis}

Genomic DNA was extracted from the body end or from the entire individual preserved in absolute ethanol using the DNeasy Blood \& Tissue Kit (Qiagen) according to the instructions given by the manufacturer. The mitochondrial cytochrome c oxidase subunit I (CO1) gene, the nuclear histone 3 (H3) gene and the nuclear ribosomal ITS region (ITS) were amplified separately by polymerase chain reaction (PCR) using the primer pairs HCO2198 (5'-TAA ACT TCA GGG TGA CCA AAA AAT CA3') and LCO1490 (5'-GGT CAA CAA ATC ATA AAG ATA TTG G-3') (Folmer et al. 1994), H3a-F (5'-ATG GCT CGT ACC AAG CAG ACV GC-3') and H3a-R (5'-ATA TCC TTR GGC ATR ATR GTG AC-3') (Colgan et al. 1998), ETTS1 (5'-TGC TTA AGT TCA GCG GGT-3') and ETTS2 (5'TAA CAA GGT TTC CGT AGG TGA A-3') (Kane \& Rollinson 1994), respectively. If amplification failed in the case of the $\mathrm{H} 3$ gene, one additional primer set (designed by AllGenetics, A Coruña, and used here with permission of ECT Oekotoxikologie GmbH, Flörsheim) was applied, H3Frid-M13F (5'GTA AAA CGA CGG CCA GTT ACC AAG CAG ACG GCH CGY-3') and H3Frid-M13tR (5'- GCG GAT AAC AAT TTC ACA CAG GGG CGT GAA TBG CRC ACA GGT-3'). PCRs were performed as described in detail previously by Dózsa-Farkas et al. (2015). Sanger sequencing was carried out by the LGC Genomics GmbH (Berlin, Germany) or by the Biomi Ltd. (Gödöllö, Hungary), while phylogenetic analyses including the search for the best fit model were performed with the MEGA 7 software (Kumar et al. 2016). The following nucleotide substitution models were applied in the analyses: for the ITS, $\mathrm{K} 2+\mathrm{G}+\mathrm{I}$; for the $\mathrm{CO} 1, \mathrm{TN} 93+\mathrm{G}+\mathrm{I}$; and for the $\mathrm{H} 3, \mathrm{~K} 2+\mathrm{G}$. Concatenation was carried out with Sequence Matrix version 1.8. (Vaidya et al. 2011). Bayesian analysis was performed with the Markov Chain Monte Carlo algorithm in two simultaneous, completely independent analyses running for 1000000 generations using MrBayes version 3.1 (Huelsenbeck \& Ronquist 2001). Posterior probabilities were calculated after the two independent runs had reached convergence, and the first $25 \%$ of the calculated trees were discarded. The concatenated phylogenetic tree comprises those specimens, which had all of the three studied regions sequenced. The obtained sequences were deposited in GenBank under the following accession codes: MK560154-MK560158 (ITS), MK580963-MK580966 (CO1) and MK562739-MK562744 (H3). Additional sequences determined in previous studies used for comparison are given in Table 1.

\section{Results}

\section{Species descriptions}

Class Clitellata Michaelsen, 1919

Order Enchytraeida Kasprzak, 1984

Family Enchytraeidae Vejdovský, 1879

Genus Fridericia Michaelsen, 1889

Fridericia baradlana sp. nov. urn:1sid:zoobank.org:act:692C37DF-0429-44CA-B989-495C256D2D43

Figs $1-3$

\section{Diagnosis}

The new species can be recognized by the following combination of characters: (1) medium sized (9$15 \mathrm{~mm}$ in vivo); segments 42-61; (2) chaetae maximum 4-5 per bundle; (3) clitellum weakly developed, girdle shaped; (4) body wall $25-35 \mu \mathrm{m}$ thick, cuticle thin $(<1 \mu \mathrm{m})$; (5) oesophageal appendages long with many branches at the end; (6) all pharyngeal glands united dorsally; (7) five pairs of preclitellar nephridia; (8) coelomo-mucocytes scarce, a/c-type, lenticytes numerous and large; (9) dorsal vessel from XIX-XXI; (10) chylus cells in XII-XIV, occupying 2 segments; (11) bursal slit T-shaped; (12) seminal vesicle in XI, not brown; (13) subneural glands in XIII-XIV; (14) sperm funnels approximately 
as long as half the body diameter, collar as wide as funnel body, spermatozoa 250-320 $\mu \mathrm{m}$ long, heads $110-150 \mu \mathrm{m}$ in vivo; (15) spermatheca with two long, arm-like diverticula variously bent or bifurcate in proximal part; ectal ducts of variable length with two ectal glands and ampullae fused proximally with common opening into oesophagus.

\section{Etymology}

Named after the type locality, Baradla cave.

\section{Material examined}

\section{Holotype}

HUNGARY - Baradla cave (Aggtelek Karst), entrance of Styx branch, from bits of decaying wood (these are remains of an old wooden bridge); $48^{\circ} 28^{\prime} 55.0^{\prime \prime} \mathrm{N}, 20^{\circ} 30^{\prime} 0.85^{\prime \prime} \mathrm{E} ; 6$ Dec. 2014; L. Dányi leg.; (F. 30. slide No. 2624, adult, stained, whole mounted specimen); ELTE.

\section{Paratypes}

HUNGARY • 2 specimens; same data as for the holotype (P. 128.1-128.2 slide No. 2598, 2623, adult, stained, whole mounted specimens) - all other paratypes from same type locality; 2 Oct. 2015; D. Angyal, G. Balázs \& L. Dányi leg.; P. 128.3-128.5 slide No. 2086, 2643, 2644, three adult, stained, P. 128.6 slide No.2664 only the forepart (with 26 segments) of an adult, stained, whole mounted specimens P.128.7 No. 2638 not stained, whole mounted specimens; P.128.8. slide No. 2639 (body end used for molecular analysis, DNA ID number 911b) not stained, whole mounted specimens; ELTE.

\section{Additional material}

HUNGARY -2 subadult specimens; same type locality; (one of them used for molecular analysis, DNA ID number 911); only in vivo.

One adult specimen was studied in vivo, stained and whole-mounted. 4 subadult specimens and 2 specimens from type locality, only in vivo.

\section{Description}

Measurements. Medium-sized, whitish worms. Holotype $9.7 \mathrm{~mm}$ long, $370 \mu \mathrm{m}$ wide at VIII and $380 \mu \mathrm{m}$ at the clitellum when fixed, 53 segments. Body length of the paratypes 9-15 mm, width 300-390 $\mu \mathrm{m}$ at VIII and 360-400 $\mu \mathrm{m}$ at the clitellum in vivo; fixed specimens: length 6.6-11.3 mm, width $310-420 \mu \mathrm{m}$ at VIII and 310-420 $\mu \mathrm{m}$ at the clitellum, segments $42-61$.

Chaetae. Chaetal formula: 2,3,4-4,3,2: 2,3,4, (5)-4,(5),3,2. Inner chaetae being slightly shorter and thinner than outer: $38-40 \times 5 \mu \mathrm{m}$ and 30-35 $\times 2,5 \mu \mathrm{m}$ (in preclitellar bundles). Behind the clitellum from ca. XXVII-XXXV only two chaetae per lateral bundle, posteriorly length about $45-55 \times 5 \mu \mathrm{m}$. Often detached chaetae in coelom (Fig. 2E).

HEAD PORE. At 0/I longitudinal slit.

DORSAL PORES. From VII. Three or four rows of hyaline epidermal gland cells per segment.

Table 1 (opposite page). List of Fridericia specimens used for molecular taxonomic analyses with collection data and GenBank accession numbers. Sequences determined in this study appear in bold. Holotypes and paratypes of new species are indicated with $\mathrm{H}$ and $\mathrm{P}$ in parentheses. 


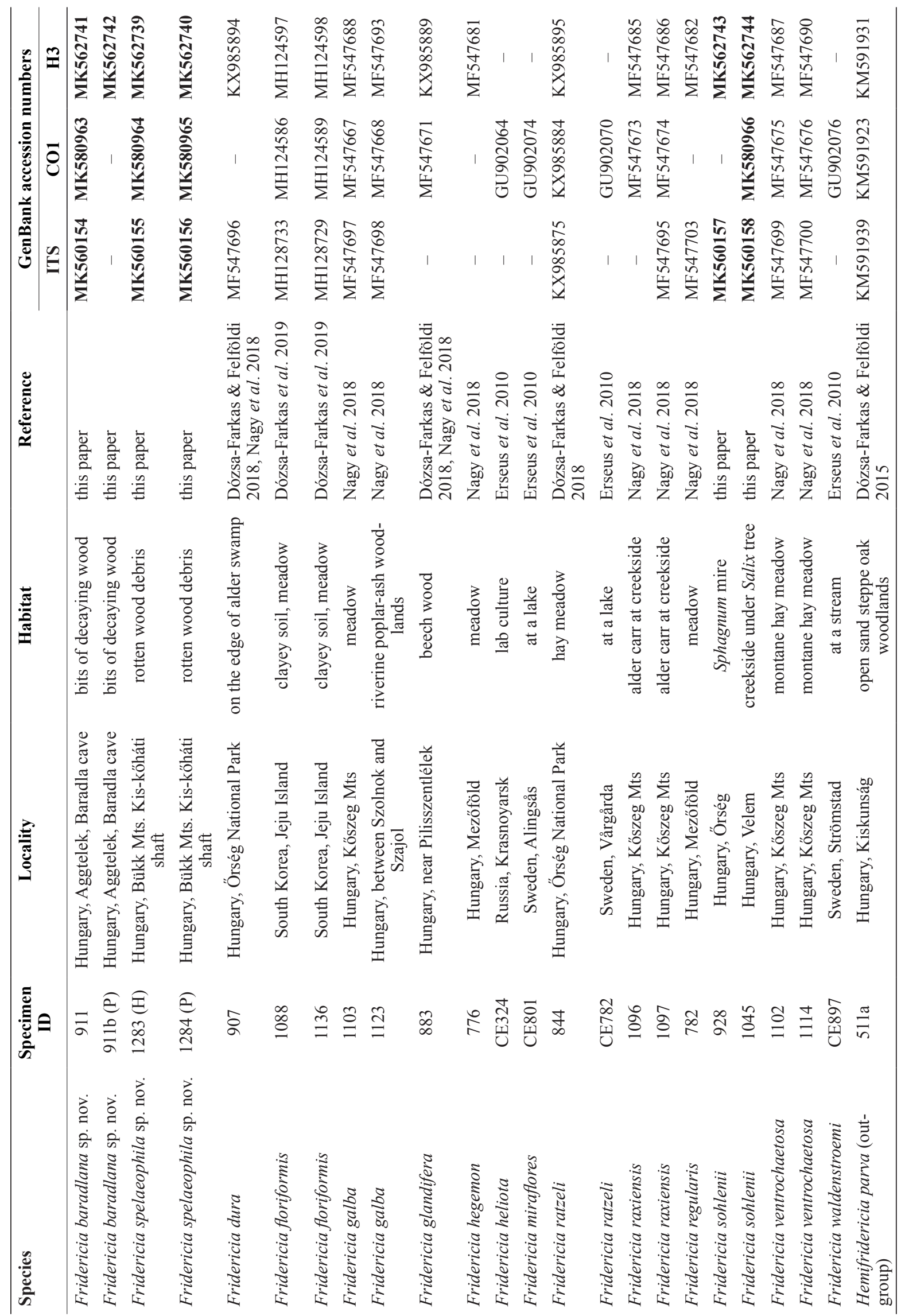


CLITELLum. In XII-1/2XIII, weakly developed, girdle-shaped, hyalocytes and granulocytes arranged in rows. Body wall about $25-35 \mu \mathrm{m}$ and cuticle $<1 \mu \mathrm{m}$ thick (Fig. $2 \mathrm{~F}$ ), in forepart slightly stronger than at the body end.

BraIN. Egg-shaped, about 160-175 $\mu \mathrm{m}$ long, about 2 times as long as wide in vivo; $130-155 \mu \mathrm{m}$ long and 1.5-2 times as long as wide when fixed (Fig. 2A).

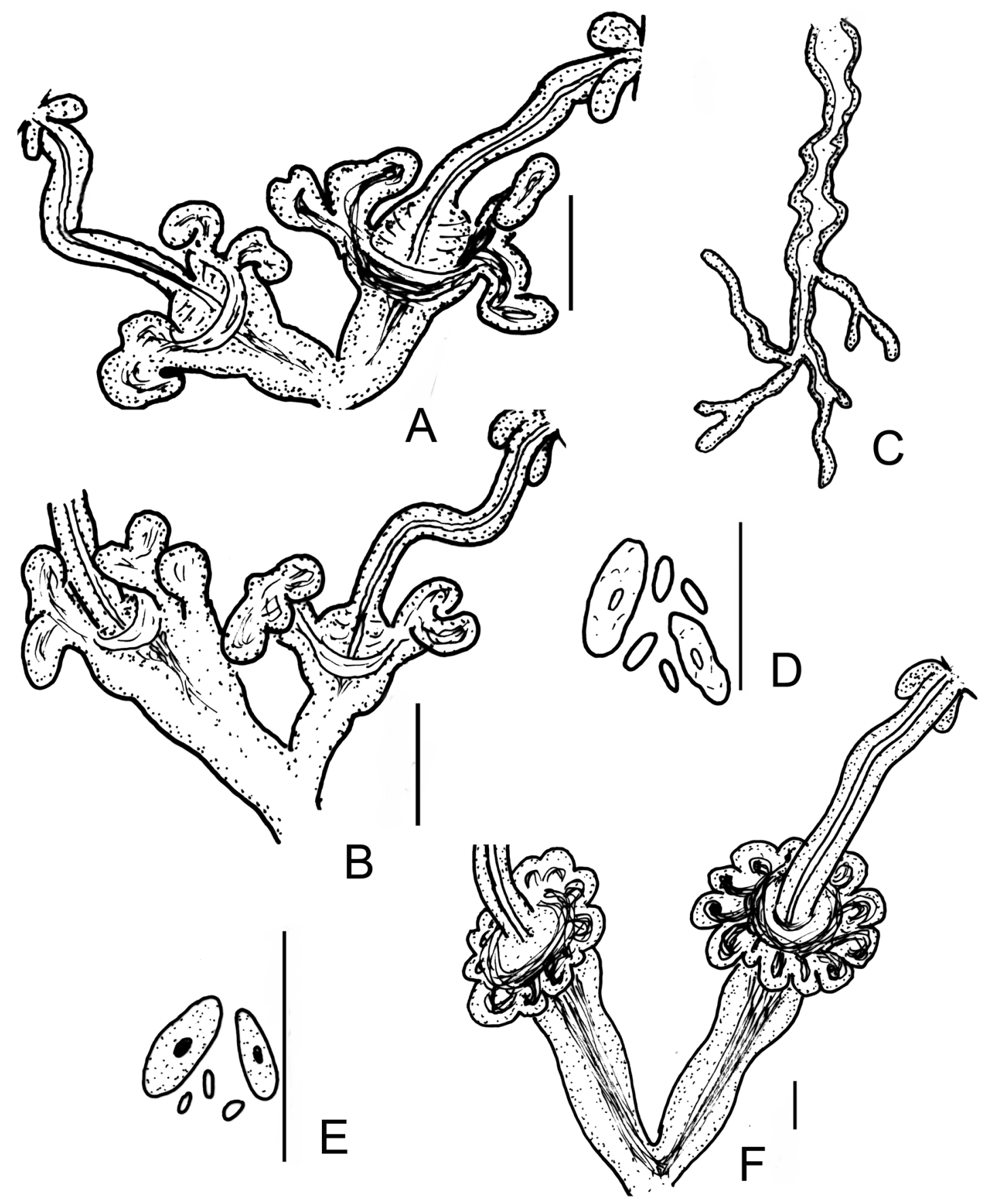

Fig. 1. A-D. Fridericia baradlana sp. nov. A-B. Spermathecae. C. Oesophageal appendage. D. Coelomocytes. E-F. Fridericia spelaeophila sp. nov. E. Coelomocytes. F. Spermathecae. Scale bars: $50 \mu \mathrm{m}$. 

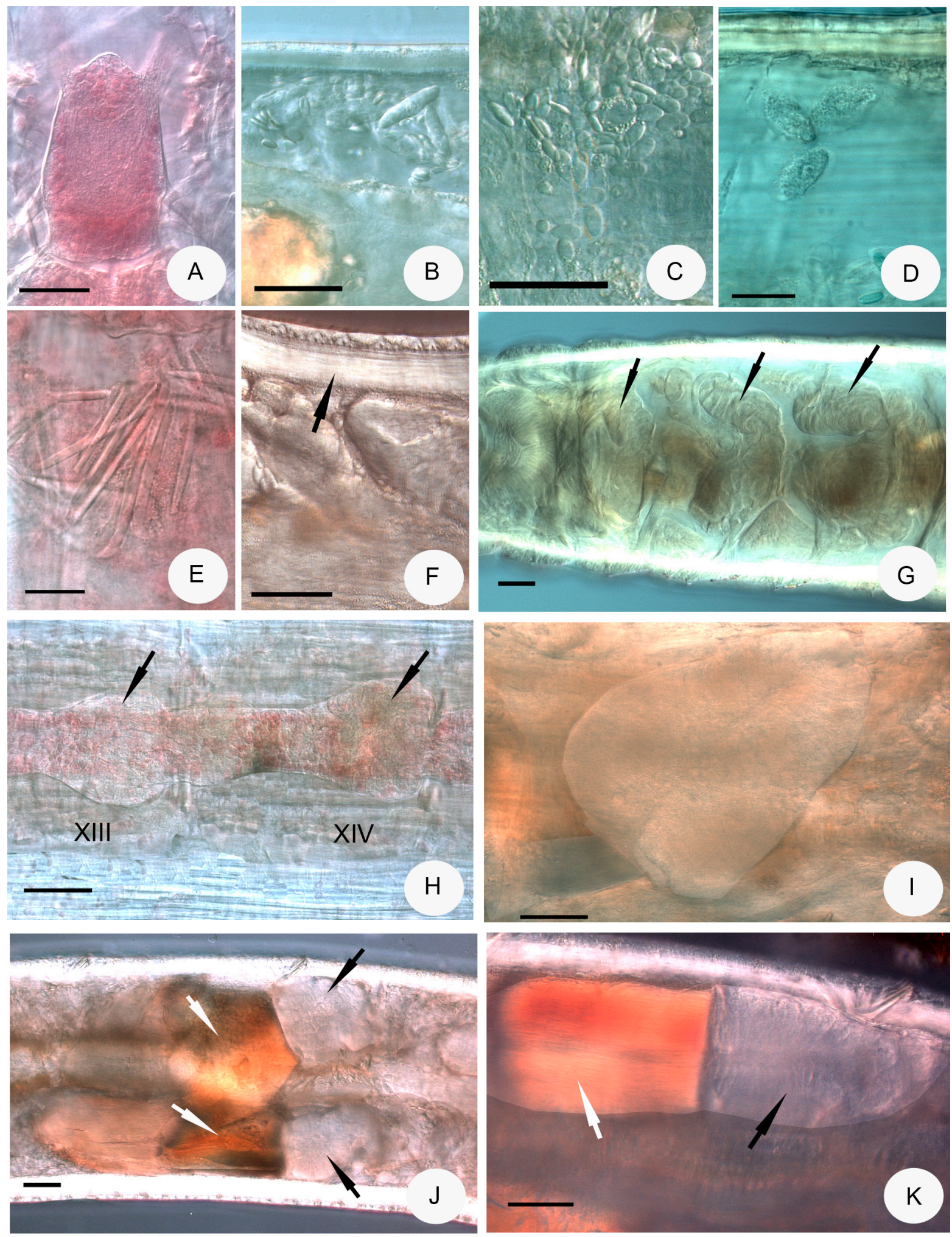

Fig. 2. Micrograph of Fridericia baradlana sp. nov. A. Brain. B-D. Coelomocytes (C. several large lenticytes). E. Detached chaetae in coelom. F. Thick body wall, thin cuticle. G. Pharyngeal glands (marked with arrows). H. Subneural glands in XIII-XIV (marked with arrows). I-K. Sperm funnels (funnel's body marked with black arrows, sperm head marked with white arrows). (B-C, F, I-K in vivo, A, F, H fixed, stained, D, G fixed, not stained. Scale bars: $50 \mu \mathrm{m}$, in D $20 \mu \mathrm{m}$. B, E from holotype.) 

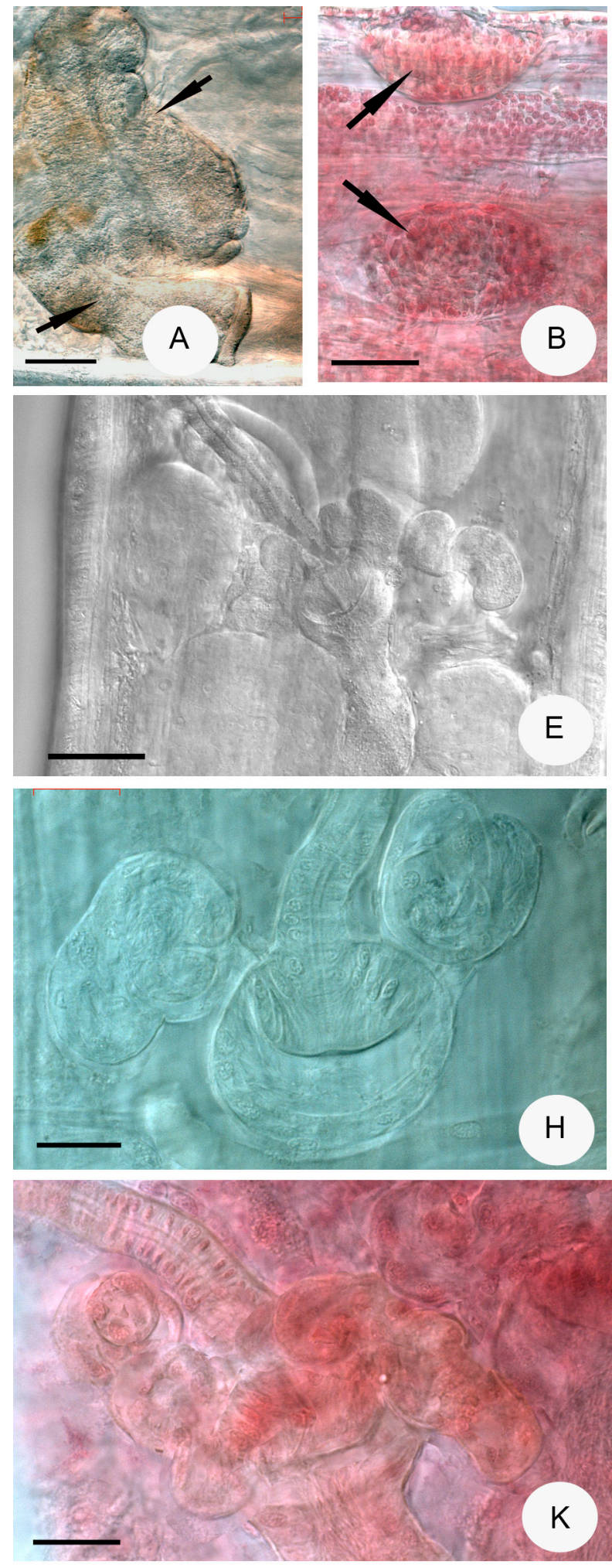
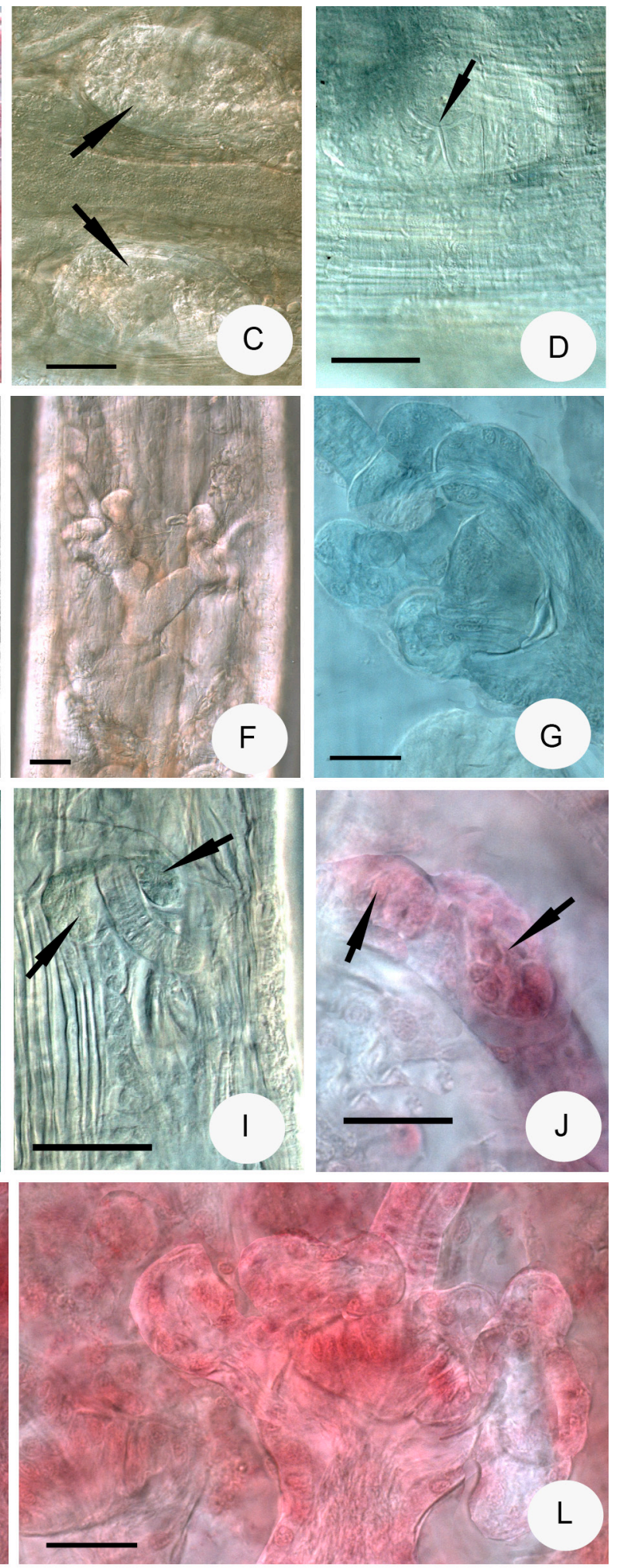

Fig. 3. Micrograph of Fridericia baradlana sp. nov. A. Sperm funnels (marked with arrows). B-C. Male copulatory organs (marked with arrows). D. Bursal slit (marked with arrow). E-H, K-L. Spermathecae. I-J. Spermathecal ectal glands (marked with arrows). (A, C, E-F in vivo, B, J, K-L fixed, stained, D, G, H-I fixed, not stained). Scale bars: $50 \mu \mathrm{m}$, in H, J-L $20 \mu \mathrm{m}, \mathrm{J}-\mathrm{L}$ from holotype. 
Oesophageal appendages. Long with many branches at the end in V (Fig. 1C). All pharyngeal glands united dorsally, those in 5/6 and 6/7 with ventral lobes, the third pairs largest (Fig. 2G).

Chloragocytes. From V, 20-23 $\mu \mathrm{m}$ long preclitellarly when fixed. Dorsal vessel from XIX-XXI, blood colourless.

Midgut PARS TUMida. Not visible.

NEPHRIDIA. Five pairs of preclitellar nephridia from $6 / 7$ to $10 / 11$, length ratio anteseptale : postseptale 1 : 1.3-1.6, medial origin of the efferent duct.

Coelomo-mucocytes. Scarce, a/c-type of Möller (1971), elliptic (Figs 1D, 2B, D), length 30-40 $\mu \mathrm{m}$ in vivo.

Lenticytes. In large numbers, large 10-15 $\mu \mathrm{m}$ long (Figs 1D, 2C). Chylus cells in XII-XIV, occupying 2 segments.

Seminal Vesicle. In XI, not brown. Sperm funnels cylindrical (Figs 2I-K, 3A), about 150-230 $\mu$ m long and about 1.5-2.3 times as long as wide in vivo.

FunNEL. Length in fixed specimens $95-150 \mu \mathrm{m}$, funnel body 1.2-2 times as long as wide but sometimes wider than long; collar as wide as funnel body.

SpermatozoA. Length: $250-320 \mu \mathrm{m}$, heads $110-150 \mu \mathrm{m}$ in vivo (Fig. 2J-K); when fixed 140-170 $\mu \mathrm{m}$ and heads $80-95 \mu \mathrm{m}$. Diameter of sperm ducts $7-9 \mu \mathrm{m}$ in vivo (9-10 $\mu \mathrm{m}$, when fixed).

Male Copulatory ORgans. 115-140 $\mu \mathrm{m}$ long, 70-80 $\mu \mathrm{m}$ wide and 50-59 $\mu \mathrm{m}$ high in vivo (Fig. 3C); $70-$ $130 \mu \mathrm{m}$ long, 50-70 $\mu \mathrm{m}$ wide and 40-60 $\mu \mathrm{m}$ high when fixed (Fig. 3B). Bursal slits T-shaped (Fig. 3D).

Subneural GLANDS. In XIII-XIV (Fig. 2H).

Spermathecae (Figs 1A-B, 3E-H). Two ectal glands of variable length (25-50 $\mu \mathrm{m}$ long) (Figs 3I-J); ectal ducts contractile, thus the length variable, about 150-250 $\mu \mathrm{m}$ long and 16-17 $\mu \mathrm{m}$ wide, canal $2 \mu \mathrm{m}$ wide in vivo (85-185 $\mu \mathrm{m}$ long, 16-17 $\mu \mathrm{m}$ wide when fixed), not widened entally, projecting into ampulla, ental bulbs about 30-40 $\mu \mathrm{m}$ wide when fixed.

Ampullae. With two long, arm-like diverticula, in their proximal parts dividing into an upper and a lower branch and variously bent (not easily visible, since the branches are overlapping with each other). Proximal part of ampullae fused, with common opening into oesophagus dorsally.

\section{Distribution and habitat}

Only known from the type locality: Baradla cave, Aggtelek Karst, Hungary.

\section{Differential diagnosis}

There are only four valid species of Fridericia with two elongate spermathecal diverticula and with the proximal parts of the two spermathecal ampullae fused, forming one common opening into the oesophagus: F. waldenstroemi Rota \& Healy, 1999, F. montafonensis Schmelz, 1998, F. profundicola Dózsa-Farkas, 1991, and F. longeaurita Boros \& Dózsa-Farkas, 2015. The new species differs from all these species (leaving other characters out of consideration) by the form of diverticula, which divide into an upper and a lower finger-like branch from their base at the ampulla. 


\section{Fridericia spelaeophila sp. nov. \\ urn:1sid:zoobank.org:act:FC10F756-F699-4776-B6DC-9C09B8A135CD}

Figs $1,4-5$

\section{Diagnosis}

The new species can be recognized by the following combination of characters: (1) large size (body length 17-29 mm in vivo); segments 48-73; (2) chaetae maximum 5-6 (7) per bundle, many detached chaetae in coelom; (3) clitellum girdle-shaped, weakly developed; (4) body wall thick (40-60 $\mu \mathrm{m}$ ) and cuticle thin (1.5-2 $\mu \mathrm{m}$ ) in vivo; (5) five preclitellar pairs of nephridia; (6) coelomo-mucocytes c-type of Möller (1971), lenticytes 5-10 $\mu \mathrm{m}$; (7) oesophageal appendages long with some branches at the end; (8) dorsal vessel from 11/12 (peculiar character); (9) seminal vesicle in XI; (10) subneural glands absent; (11) sperm funnel rounded, about $1 / 3$ as long as body diameter, collar about as wide as funnel diameter, spermatozoa 150-170 $\mu \mathrm{m}$ long, heads $50-70 \mu \mathrm{m}$ when fixed; (12) spermatheca with 10-15 sessile diverticula with sperm in them, ectal duct of variable length with 2-3 large ectal glands of variable size; proximal part of ampullae conspicuous, fused, with common opening into oesophagus dorsally.

\section{Etymology}

From the composition of spelaeo (Latin: spēlaeum, i) ‘cavern' and phila (Latin: -philus, -phila) 'lover', as it was collected in a cave.

\section{Material examined}

\section{Holotype}

HUNGARY • Kis-kőháti shaft (Bükk Mts), coarse woody debris; 4804'05.1" N, 20³3'07.7" E; 1 May 2018; L. Dányi \& G. Balázs leg. (F.31. slide No. 2607. adult, stained whole-mounted specimen, last 11 segments used for molecular analysis, DNA ID number 1283); ELTE.

\section{Paratypes}

HUNGARY • 2 specimens; same data as for the holotype (P. 129.1-129.2 slide No. 2646, 2650, last 19 segments for molecular analysis, DNA ID number 1284).

HUNGARY • 3 specimens; Szepesi-Láner cave system (Bükk Mts): Láner Olivér cave, debris of decaying wood and clay; $48^{\circ} 05^{\prime} 59.8^{\prime \prime}$ N, $20^{\circ} 35^{\prime} 41.7 ”$ E; 16 Oct. 2014; D. Angyal, G. Balázs \& L. Dányi leg. (P. 130.1-130.3 slide No. 2647a+b; 2667a+b; 2085a+b) - 8 specimens; 27 Jan. 2015; D. Angyal, G. Balázs \& L. Dányi leg. (P. 130.4-130.11 slide No. 2648; 2649a+b, 2651a+b; 2665a+b; 2668a+b; 2669a+b; 2670a+b; 2676a+b); ELTE.

\section{Additional material}

2 juvenile specimens only in vivo from Láner Olivér cave. Three adult specimens were fixed on site, but due to the improper fixation these were not suitable for detailed morphological analysis.

\section{Description}

MEASUREMENTS. Large, whitish worms. Holotype 59 segments, $23.5 \mathrm{~mm}$ long, $0.75 \mathrm{~mm}$ wide at VIII and $0.80 \mathrm{~mm}$ at the clitellum in vivo; fixed specimen: $12.7 \mathrm{~mm}$ long, $0.89 \mathrm{~mm}$ wide at VIII and $1.0 \mathrm{~mm}$ at the clitellum (later from this specimen, 10 segments were taken for molecular analysis, DNA ID number 1283). Body length of the paratypes $17-27 \mathrm{~mm}$, width $0.60-0.78 \mathrm{~mm}$ at VIII and $0.77-0.90 \mathrm{~mm}$ at the clitellum in vivo; fixed specimens $10-29 \mathrm{~mm}$ long, width $0.75-1.2 \mathrm{~mm}$ at VIII and $0.90-1.25 \mathrm{~mm}$ at the clitellum; segments 48-73.

Chattae. Chaetal formula: 2,3,4,5,(6,7)-5,4,2 : (2),4,5,6,(7)-(6),4,3,2. Mostly inner chaetae being slightly shorter and thinner than the outer ones: e.g. 50-70 $\times 5-7 \mu \mathrm{m}$ and 74-100 $\times 9-11 \mu \mathrm{m}$ (Fig. 4C), 
but sometimes placed irregularly (e.g. from one side to the other half in line: $78 \times 8 ; 100 \times 9 ; 100 \times 9$; $75 \times 8,93 \times 9 \mu \mathrm{m}$ ) or almost equally long and thick in preclitellar bundles (Fig. 4E). Many detached chaetae in packages in coelomic cavity (Fig. 4F). In these packages the length of largest chaetae was $104 \times 8-9 \mu \mathrm{m}$, the length of the smallest one $47 \times 6 \mu \mathrm{m}$. From segment XVI or at the latest from XXII, in the lateral bundles only 2 chaetae, length about $80 \times 4.5-7 \mu \mathrm{m}$.

HEAD PORE. A longitudinal slit at 0/I (Fig. 4B).

DORSAL PORES. From VII. Epidermal gland cells inconspicuous.

Clitellum. In XII-1/2XIII, weakly developed, girdle-shaped, gland cells irregularly arranged (Fig. 4D), between bursal slits mostly granulocytes.

Body waLl. Thick, about 35-60 $\mu \mathrm{m}$, cuticle thin, about 1-2 $\mu \mathrm{m}$ when fixed.

BraIN (Fig. 4A). Egg-shaped, about $170 \mu \mathrm{m}$ long, about 1.2-1.6 times as long as wide (fixed).

Oesophageal APPENDAges. Long, with some distal branches in V. All pharyngeal glands united dorsally and with short ventral lobes.

Chloragocytes. From V. Dorsal vessel from 11/12 (in one case in XII), with large heart-like expansions in XI-VIII, blood colourless.

Chylus cells and midgut Pars tumida. Not visible (probably because the intestine was full of woodfragments and crystals (most probably calcite) in all studied specimens; Fig. 4I).

NePHRIDIA. Five pairs of preclitellar nephridia from $6 / 7$ to $10 / 11$, length ratio anteseptale : postseptale 1 : 1.3-1.4 (Fig. 4H), adseptal origin of efferent duct.

Coelomo-mucocytes. c-type: with smooth outline, elliptic, matrix pale, with well visible nucleoli, 17$26 \mu \mathrm{m}$ long in vivo, 13-25 $\mu \mathrm{m}$ long when fixed (Figs 1E, 4G).

LeNTiCytes. 5-10 $\mu \mathrm{m}$ long.

Seminal VesicLe. In XI or X-XI.

SPERM FunNELs. Mostly roundish, about 270-300 $\mu \mathrm{m}$ long and about 1.4-1.6 times longer than wide in vivo (Fig. 4K). Funnel (Figs 4K-L, 5A) length in fixed specimens 180-300 $\mu \mathrm{m}$, funnel body 1.2-1.4 times longer than wide, sometimes two times as long as wide; collar about as wide as funnel body (Figs 4L, 5A). Length of spermatozoa not measurable in vivo, heads 110-130 $\mu \mathrm{m}$ (Fig. 4K), in fixed specimens, spermatozoa $150-170 \mu \mathrm{m}$ long, sperm heads $50-70 \mu \mathrm{m}$. Diameter of sperm ducts $8-9 \mu \mathrm{m}$ when fixed.

Male copulatory organs. 100-200 $\mu \mathrm{m}$ long, 90-180 $\mu \mathrm{m}$ wide and about $80 \mu \mathrm{m}$ high when fixed (Fig. 4J), glandular body weakly developed. Bursal slits T-shaped.

SubNeURAL GLANDS. Absent.

Spermathecae (Figs 1F, 5B-H). Two or three large ectal glands, size variable (35-97 $\mu \mathrm{m}$ long in vivo and 40-90 $\mu \mathrm{m}$ long, fixed); ectal ducts about 310-340 $\mu \mathrm{m}$ long and 37-38 $\mu \mathrm{m}$ wide, canal 8-8.5 $\mu \mathrm{m}$ wide in vivo (when fixed, variable: $150-300 \mu \mathrm{m}$ long, $27-40 \mu \mathrm{m}$ wide, canal 6-8 $\mu \mathrm{m}$ ), not or slightly widened entally, projecting into ampulla, ental bulbs about 70-84 $\mu$ m wide when fixed. 

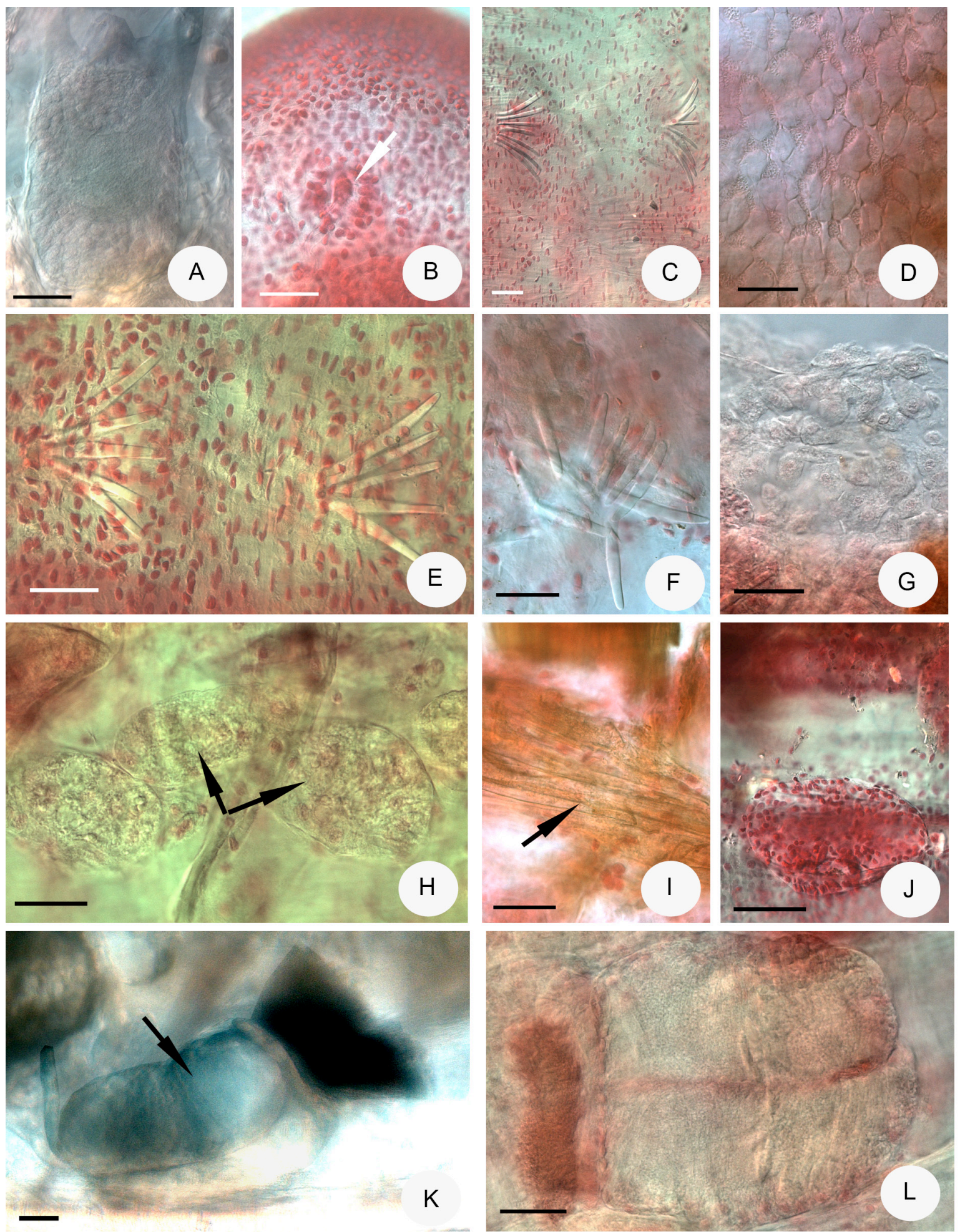

Fig. 4. Micrograph of Fridericia spelaeophila sp. nov. A. Brain. B. Head pore (marked with arrow). C. Chaetae in V-VII. D. Clitellar glands, dorsal view. E. Chaetae in VII-VIII. F. Detached chaetae in coelom. G. Coelomocytes. H. Nephridium at 7/8 (pre- and postseptale marked with arrows). I. Fragments of decaying wood in the intestine (marked with arrow). J. Male copulatory organs, lateral view. K-L. Sperm funnels. (A, K in vivo, B-J, L fixed, stained. Scale bars: $50 \mu \mathrm{m}$. B, G from holotype, K from DNA 1283.) 

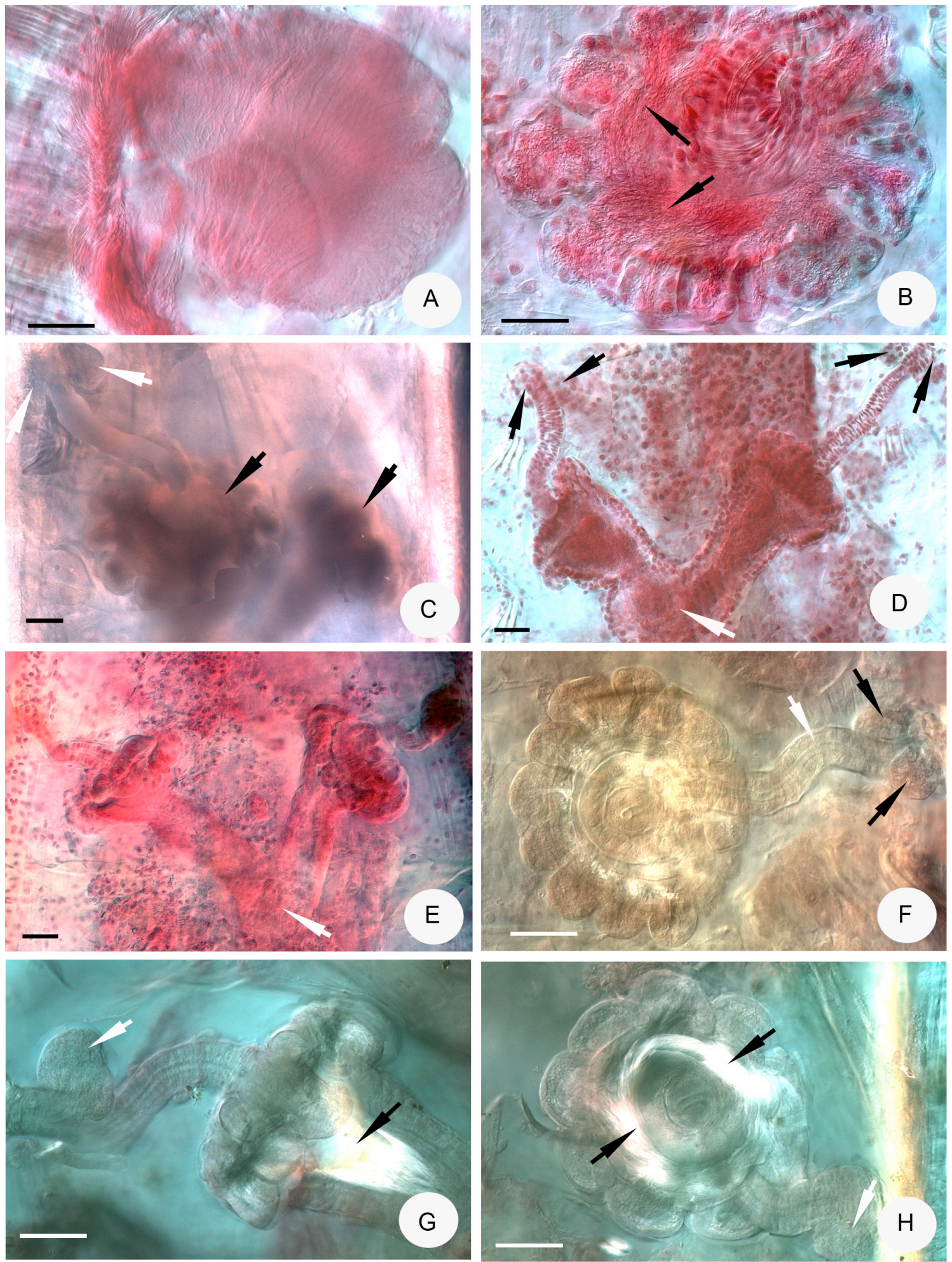

Fig. 5. Micrograph of Fridericia spelaeophila sp. nov. A. Sperm funnel. B, H. Spermathecal ampullae (sperm in ampulla marked with arrows). C-G. Spermathecae. (In C, diverticula marked with black arrows, ectal glands with white arrow. D-E. Fused proximal parts marked with white arrows, ectal glands with black arrows. F. Ectal duct marked with white arrow, ectal glands with black arrows. G. Ectal glands marked with white arrow, the refractive sperm in ampullar distal part marked with black arrow). All pictures fixed and stained. E from holotype. Scale bars: $50 \mu \mathrm{m}$. 

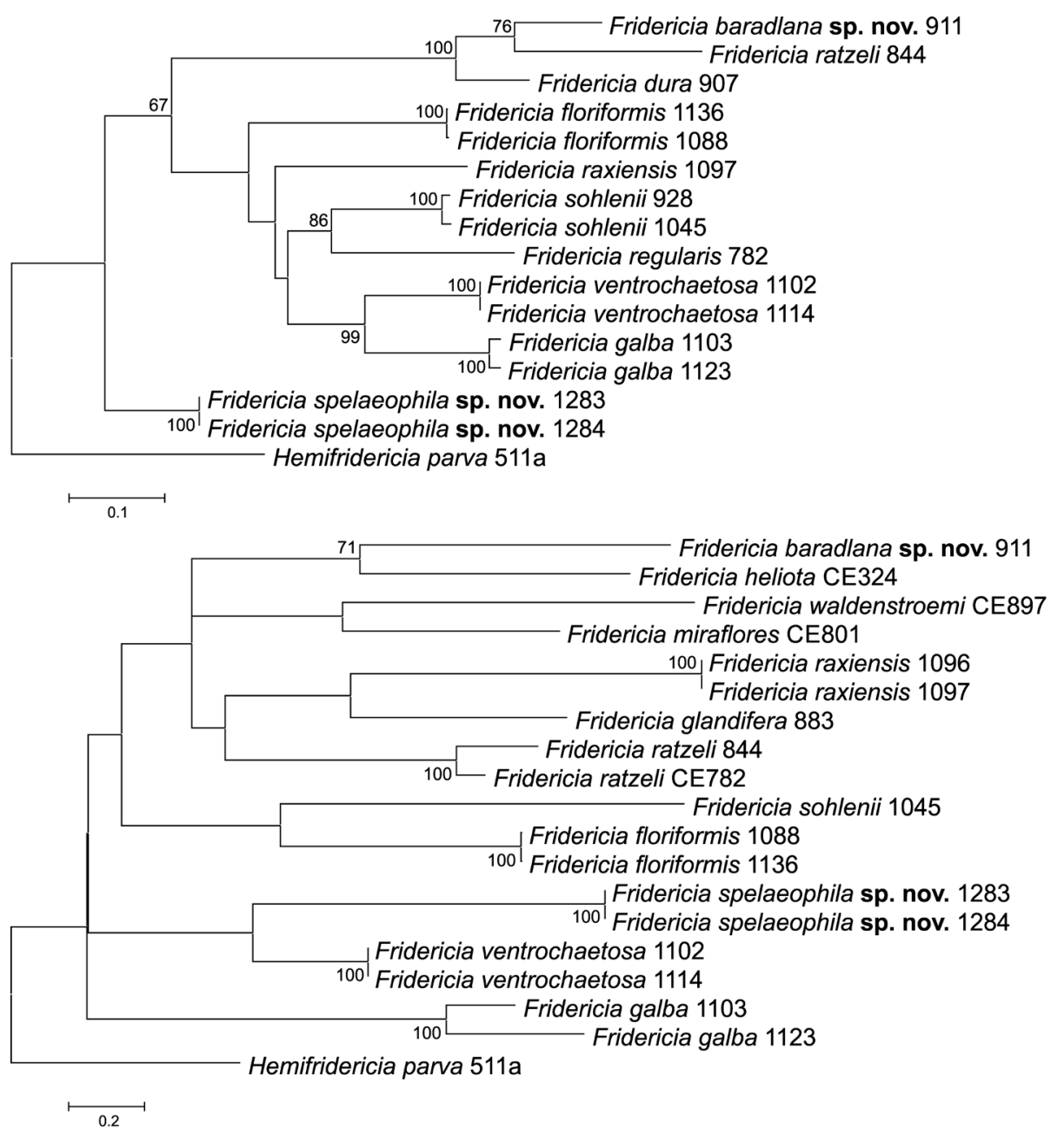

A

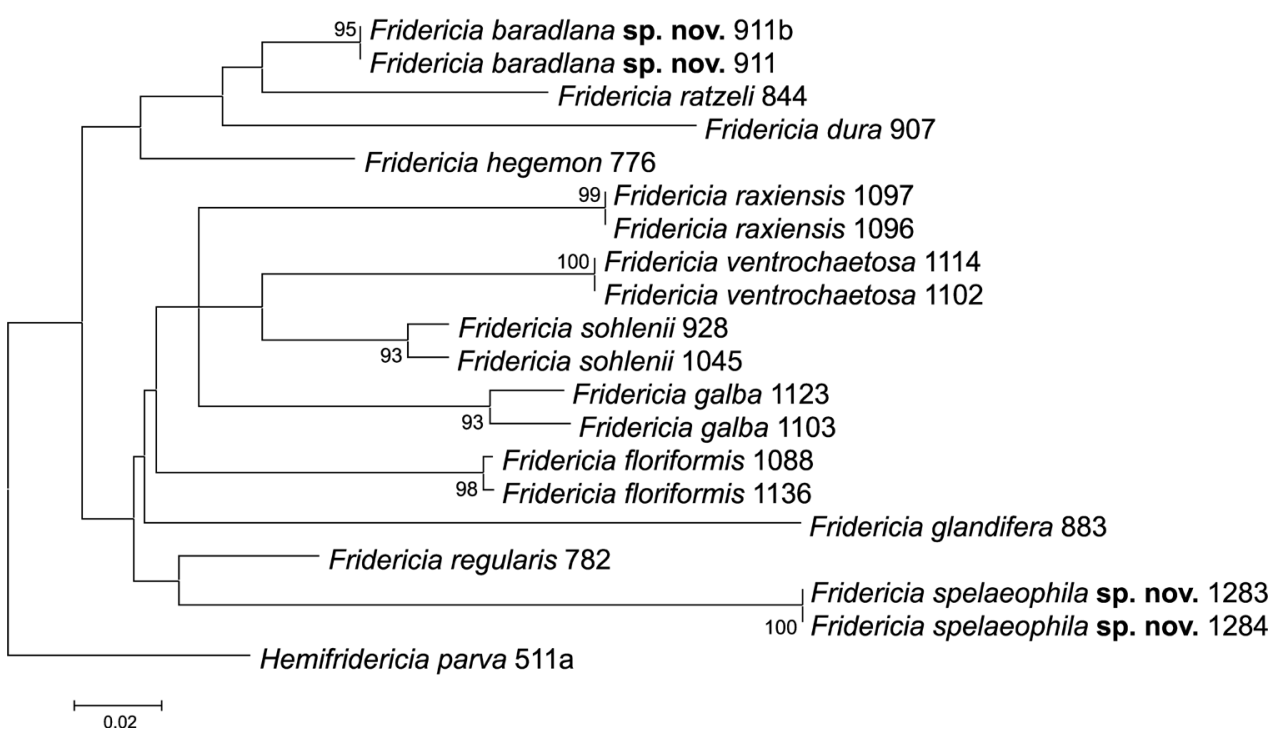

Fig. 6. Maximum likelihood (ML) trees of studied Fridericia species based on the ITS region (A), CO1 (B) and $\mathrm{H} 3$ genes (C). Bootstrap values greater than 50 are shown at the nodes. Sequences from new species described here appear in bold. A. ML tree of the ITS region based on 821 nucleotide positions. B. ML tree of the CO1 gene based on 388 nucleotide positions. C. ML tree of the H3 gene based on 202 nucleotide positions. 
Ampullae. Surrounded distally by about 10-15 sessile diverticula (Figs 5B, F, G-H), these diverticula are 50-90 $\mu \mathrm{m}$ long and 40-90 $\mu \mathrm{m}$ wide. Sperm in a circle in lumen of ampullar distal part and also in the diverticula (Figs 5B, G-H). Diameter of ampulla and diverticula together 180-300 $\mu \mathrm{m}$ when fixed. Proximal part of ampullae conspicuous, 100-320 $\mu \mathrm{m}$ long when fixed and fused into one common duct, which opens into oesophagus dorsally (Figs 5D-E). Often the length of two the proximal part is different (e.g. $130 \mu \mathrm{m}$ and $255 \mu \mathrm{m}$ long). 1-2 rather small mature eggs at a time.

\section{Distribution and habitat}

In Kis-kőháti shaft and Szepesi-Láner cave system, in decaying wood, Bükk Mts, Hungary.

\section{Differential diagnosis}

The new species differs from all Fridericia species described up to now by the unusual origin of the dorsal vessel before clitellar segments (mostly in XI from septum 11/12, only in one specimen in XII). Only in the following species of Fridericia does the dorsal vessel originate in XIII (intraclitellarly) or XIV, but not preclitellarly: F. parasitica Černosvitov, 1928, F. pretoriana Stephenson, 1930, F. monochaeta Rota, 1995, F sousai Schmelz, 2013 and F. cusanica Schmelz, 2003. Other differences: F. sousai and F. monochaeta are smaller (38-43 and 30-35 segments) and have only two spermathecal diverticula; F. parasitica has 40-52 segments but only 4 spermathecal diverticula; F. pretoriana has 36-51 segments and $F$. cusanica 32-35 segments and spermatheca without diverticula.

\section{Results of molecular analysis}

In total, 5, 4 and 6 new sequences were obtained from the studied Fridericia species in the case of ITS, $\mathrm{CO} 1$ and $\mathrm{H} 3$, respectively. Unfortunately, we failed to amplify the ITS region and CO1 gene from some specimens, which was probably due to the improper hybridization of PCR primer sequences to the extracted genomic DNA. Results of molecular analysis confirmed that Fridericia baradlana sp. nov. and Fridericia spelaeophila sp. nov. are distinct species, since based on the three studied regions, sequences acquired from the examined specimens were clearly separated in the phylogenetic trees (Figs 6-7).

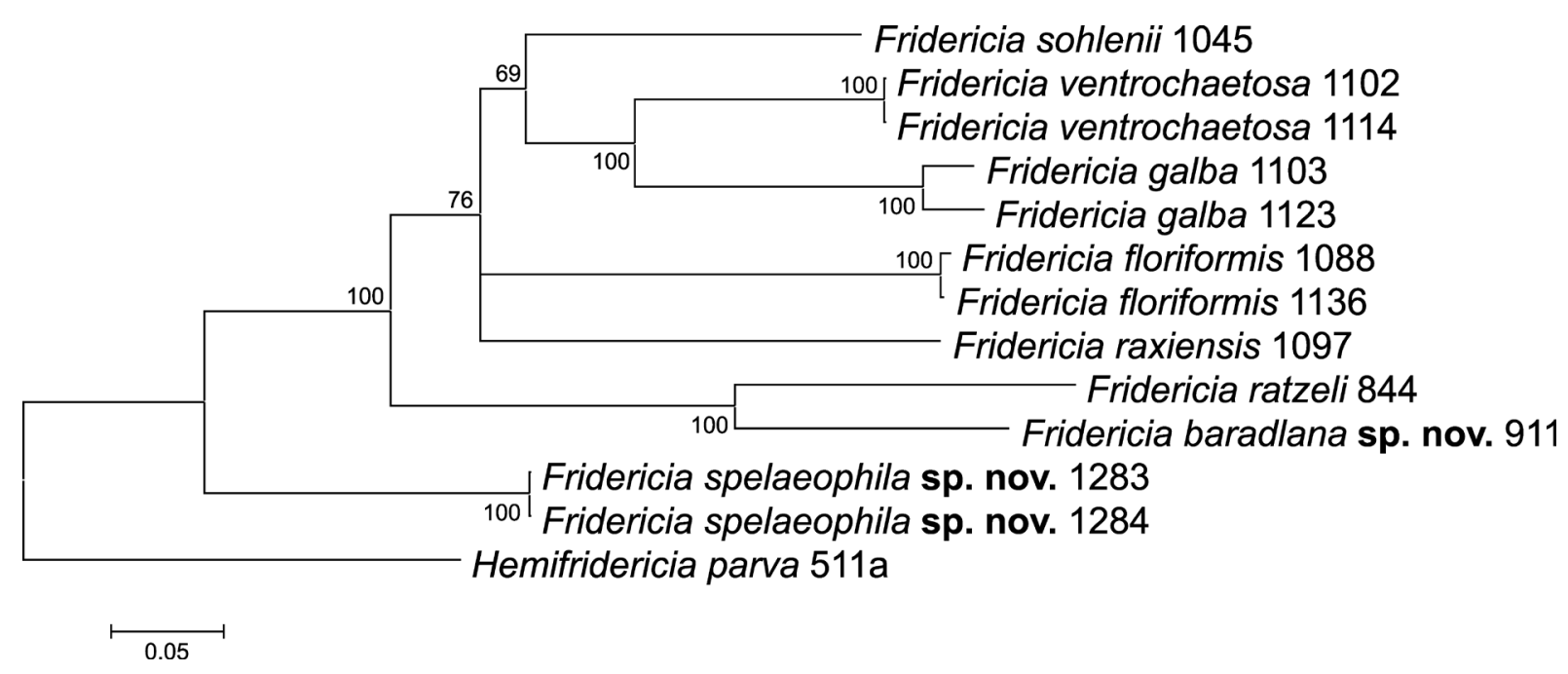

Fig. 7. Concatenated phylogenetic tree of the two new and other Fridericia species based on 1447 nucleotid positions (which comprise the CO1, H3 genes and the ITS region). Posterior probabilities greater than 50 are shown at the nodes. Sequences from new species described here appear in bold. 


\section{Discussion}

In Hungary, enchytraeids have been reported from three caves so far: 17 species from the Baradla cave in the Aggtelek Karst (Dózsa-Farkas 1970, 1974), 3 species from the Meteor cave in the Bükk Mts (Bajomi 1969) and 4 species from the Szemlö-hegyi aragonite cave near Budapest (Dózsa-Farkas 1989). Most of the recorded species are widespread and common, and none of them can be considered troglobiotic.

From the two new species, $F$. spelaeophila sp. nov. (which has been detected in two localities) surely prefers habitats with higher moisture, and it has been found up to now only in a cave and a shaft (its name alludes to this), but we cannot state that it is a troglobiotic species. The troglobiotic, endemic status of F. baradlana sp. nov. is also not sure, although it has been only recently discovered in the intensively explored Baradla cave and was not recorded at any other site. Based on their intestinal content, specimens of both species found appropriate food in the decaying wood.

\section{Acknowledgements}

This study was supported by the National Research, Development and Innovation Office (108582 NKFIH). The authors are thankful to Dóra Angyal, Gergely Balázs and László Dányi for collecting worms and substrate samples.

\section{References}

Anda D., Krett G., Makk J., Márialigeti K., Mádl-Szőnyi J. \& Borsodi A.K. 2017. Comparison of bacterial and archaeal communities from different habitats of the hypogenic Molnár János Cave of the Buda Thermal Karst System (Hungary). Journal of Cave and Karst Studies 79 (2): 113-121. https://doi.org/10.4311/2015MB0134

Bajomi D. 1969. Examen faunistique de la grotte "Meteor" (Hongrie). Opuscula Zoologica Budapest 9 (2): 235-247.

Botea F. 1973. Enchytréidés (Oligochaeta) du domaine souterrain de Roumanie, Note 2. Travaux de l'Institut de Speologie "Emile Racovitza" 12: 87-111.

Botea F. 1984. A new species of Marionina (Oligochaeta, Enchytraeidae) in the caves of Romania: Marionina serbui n.sp. Travaux de l'Institut de Speologie "Emile Racovitza" 33: 3-5.

Colgan D.J., McLauchlan A.A., Wilson G.D.F., Livingston S.P., Edgecombe G.D., Macaranas J., Cassis G. \& Gray M.R. 1998. Histone H3 and U2 snRNA DNA sequences and arthropod molecular evolution. Australian Journal of Zoology 46: 419-437. https://doi.org/10.1071/ZO98048

Creuzé des Châtelliers M., Juget J., Lafont M. \& Martin P. 2009. Subterranean aquatic Oligochaeta. Freshwater Biology 54: 678-690. https://doi.org/10.1111/j.1365-2427.2009.02173.x

Dózsa-Farkas K. 1970. The description of three new species and some data to the enchytraeid fauna of the Baradla Cave, Hungary. Opuscula Zoologica Budapest 10: 241-251.

Dózsa-Farkas K. 1974. A new Fridericia species (Oligochaeta: Enchytraeidae). Acta Zoologica Hungarica 20 (1-2): 27-32.

Dózsa-Farkas K. 1989. Zur Höhlen-Enchytraeidenfauna Ungarns (Oligochaeta). Mémoires de Biospéologie 17: 157-161.

Dózsa-Farkas K. 2019. Enchytraeids of Hungary (Annelida: Clitellata: Enchytraeidae). Pedozoologica Hungarica 7. Eötvös University Press, Budapest.

Dózsa-Farkas K. \& Felföldi T. 2015. Unexpected occurrence of Hemifridericia bivesiculata Christensen \& Dózsa-Farkas, 2006 in Hungary, a species presumed to be endemic to Devon Island, Canada, and its 
comparative analysis with $H$. parva Nielsen \& Christensen, 1959 (Enchytraeidae, Oligochaeta). Zootaxa 3914 (2): 185-194. https://doi.org/10.11646/zootaxa.3914.2.8

Dózsa-Farkas K., Felföldi T. \& Hong Y. 2015. New enchytraeid species (Enchytraeidae, Oligochaeta) from Korea. Zootaxa 4006: 171-197. https://doi.org/10.11646/zootaxa.4006.1.9

Dózsa-Farkas K. \& Felföldi T. 2018. The enchytraeid fauna (Enchytraeidae, Clitellata) of the Rax Mountain (Austria) with description of two new species and comparison of Fridericia discifera Healy, 1975 and F. alpica sp. n. Acta Zoologica Academiae Scientiarum Hungaricae 64 (1): 1-20. https://doi.org/10.17109/AZH.64.1.1.2018

Dózsa-Farkas K., Felföldi T., Nagy H. \& Hong Y. 2019. Two new enchytraeid species from Jeju Island, Korea (Annelida, Clitellata). ZooKeys 824: 87-108. https://doi.org/10.3897/zookeys.824.25544

Dudich E. 1932. Biologie der Aggteleker Tropfsteinhöhle "Baradla" in Ungarn. Speläologische Monographien 12. Wien XII+246.

Erőss A., Mádl-Szőnyi J., Surbeck H., Horváth Á., Goldscheider N. \& Csoma A.É. 2012. Radionuclides as natural tracers for the characterization of fluids in regional discharge areas, Buda Thermal Karst, Hungary. Journal of Hydrology 426-427: 124-137. https://doi.org/10.1016/j.jhydrol.2012.01.031

Erseus C., Rota E., Matamoros L. \& De Wit P. 2010. Molecular phylogeny of Enchytraeidae (Annelida, Clitellata). Molecular Phylogenetics and Evolution 57 (2): 849-858.

https://doi.org/10.1016/j.ympev.2010.07.005

Folmer O., Black M., Hoeh W., Lutz R. \& Vrijenhoek R. 1994. DNA primers for amplification of mitochondrial cytochrome c oxidase subunit I from diverse metazoan invertebrates. Molecular Marine Biology and Biotechnology 3: 294-299.

Huelsenbeck J.P. \& Ronquist F. 2001. MRBAYES: Bayesian inference of phylogeny. Bioinformatics 17: 754-755. https://doi.org/10.1093/bioinformatics/17.8.754

Kane R.A. \& Rollinson D. 1994. Repetitive sequences in the ribosomal DNA internal transcribed spacer of Schistosoma haematobium, Schistosoma intercalatum and Schistosoma mattheii. Molecular and Biochemical Parasitology 63: 153-156. https://doi.org/10.1016/0166-6851(94)90018-3

Kumar S., Stecher G. \& Tamura K. 2016. MEGA7: Molecular Evolutionary Genetics Analysis version 7.0 for bigger datasets. Molecular Biology and Evolution 33: 1870-1874.

https://doi.org/10.1093/molbev/msw054

Möller F. 1971. Systematische Untersuchungen an terricolen Enchytraeiden einiger Grünlandstandorte im Bezirk Potsdam. Mitteilungen aus dem Zoologischen Museum in Berlin 47: 131-167.

https://doi.org/10.11646/zootaxa.4496.1.8

Nagy H., Felföldi T. \& Dózsa-Farkas K. 2018. Morphological and molecular distinction of two Fridericia species (Clitellata, Enchytraeidae) having same spermatheca-type. Zootaxa 4496: 111-123.

https://doi.org/10.11646/zootaxa.4496.1.8

O'Connor F.B. 1962. The extraction of Enchytraeidae from soil. In: Murphy P.W. (ed.) Progress in Soil Zoology. Butterworths, London.

Salamon G., Dányi L., Angyal D., Balázs G. \& Forró L. 2015. A Baradla gerinctelen faunája. In: Gruber. P., Gaál L. (eds) A Baradla-Domica barlangrendszer: A barlang amely összeköt. [Invertebrate fauna of Baradla cave]. The Baradla-Domica cave system. Jósvafö.

Schmelz R. M. 2003. Taxonomy of Fridericia (Oligochaeta, Enchytraeidae). Revision of species with morphological and biochemical methods. Abhandlungen des Naturwissenschaftlichen Vereins in Hamburg, Neue Folge 38. Goecke \& Evers Keltern-Weiler, Göttingen. 
Schmelz R.M. \& Collado R. 2010. A guide to European terrestrial and freshwater species of Enchytraeidae (Oligochaeta). Soil Organisms 82 (1): 1-176.

Vaidya G., Lohman D.J. \& Meier R. 2011. SequenceMatrix: concatenation software for the fast assembly of multi-gene datasets with character set and codon information. Cladistics 27 (2): 171-180.

https://doi.org/10.1111/j.1096-0031.2010.00329.x

Manuscript received: 4 March 2019

Manuscript accepted: 9 June 2019

Published on: 17 September 2019

Topic editor: Rudy Jocqué

Desk editor: Marianne Salaün

Printed versions of all papers are also deposited in the libraries of the institutes that are members of the EJT consortium: Muséum national d'Histoire naturelle, Paris, France; Botanic Garden Meise, Belgium; Royal Museum for Central Africa, Tervuren, Belgium; Royal Belgian Institute of Natural Sciences, Brussels, Belgium; Natural History Museum of Denmark, Copenhagen, Denmark; Naturalis Biodiversity Center, Leiden, the Netherlands; Museo Nacional de Ciencias Naturales-CSIC, Madrid, Spain; Real Jardín Botánico de Madrid CSIC, Spain; Zoological Research Museum Alexander Koenig, Bonn, Germany; National Museum, Prague, Czech Republic. 